\title{
Identification of Elite Potato Clones with Resistance to Late Blight Through Participatory Varietal Selection in Peru
}

\author{
Manuel Gastelo ${ }^{1}$ (D) Gabriela Burgos ${ }^{1}$ (D) - Carolina Bastos $^{2}$ (D) \\ Juan Miguel Perez ${ }^{3}$ (D) Ronal Otiniano ${ }^{3}$ (D) $\cdot$ Hector Cabrera $^{4}$ (D) \\ Raul Ccanto ${ }^{5}$ (D) Maria Mayer de Scurrah $^{5}$ (D) $\cdot$ Thomas zum Felde $^{1}$ (D)

\begin{abstract}
Potato is the most important crop in Peru and late blight is the main disease affecting the crop. However, new varieties that are resistant to late blight often lack other traits that farmers and consumers prefer. Using participatory varietal selection, this study seeks to identify clones with high potential to become varieties with resistance to late blight but also feature a high marketable tuber yield and other preferred agronomic traits. During 2016-2017, 36 clones previously selected for high levels of resistance to late blight from population B developed by the International Potato Center, and three varieties used as controls (INIA 302 Amarilis moderately resistant, INIA303 Canchan and Yungay susceptible to late blight), were evaluated in five Peruvian locations. At harvest, five clones were selected based on (i) evaluations made by farmers through Participatory Varietal Selection, (ii) analysis of mixed models and Best Linear Unbiased Predictors for tuber yield, (iii) low glycoalkaloid content in tubers, and (iv) good organoleptic quality. These clones were evaluated again during 2017-2018 in four locations. Resistance to late blight and good marketable tuber yields were identified as the most important criteria for the selection of a new potato variety. The clones CIP308488.92, CIP308495.227 and CIP308478.59 were selected as promising clones having resistance to late blight and tuber yield superior to the local varieties, INIA-303 Canchan, Yungay, as well as good organoleptic quality and low glycoalkaloid content. These clones can be suggested for variety release in similar agroecological environments.
\end{abstract}

Keywords Glycoalkaloids · Late blight · Organoleptic quality · Participatory varietal selection · Potato $\cdot$ Tuber yield

Manuel Gastelo

mgastelo@cgiar.org

Extended author information available on the last page of the article 


\section{Introduction}

In the Andes Mountains of Peru, potato is the most important crop with a cultivated area of 330,862 hectares in 2018 and an average yield of $14.9 \mathrm{t} \mathrm{ha}^{-1}$ (Ministerio de Agricultura y Riego del Peru 2018). Potato is the main source of food and income for small producers in the Andean region and is one of the main components of the regional food basket (Egusquiza 2000). The most consumed varieties in Peru-INIA303 Canchan, Yungay and Unica - occupy more than $70 \%$ of the planted area but are susceptible to late blight (LB) disease, which is increasing its prevalence as a consequence of climate change (Litschmann et al. 2018). The International Potato Center (CIP) has developed a population of improved potato clones with high levels of resistance to this disease, high yields of tubers and other agronomic characteristics and high potential for release as varieties (population B3C3) (Landeo et al. 2001, 2008; https://data.cipotato.org/dataset.xhtml?persistentId=doi\%3A10.21223\%2FZOKTTA). These varieties can flourish under agroecological environments brought about by climate change.

Conventional selection of new varieties is based on agronomic characteristics such as high yields, resistance to pests and diseases and maturation rates (earliness), as well as being necessary to integrate other key preferences of actors in the potato value chain, such as consumers and wholesalers who have specific needs regarding taste, colour, price and cooking type (Cuesta and Andrade 2001; Gabriel et al. 2002; Pradel et al. 2017). Thus, the adoption rate of improved, high-yielding and disease-tolerant potato varieties will be higher by also integrating it into a seed production system (Labarta 2015).

To assure fast dissemination and adoption of improved varieties after their release, it is necessary to apply appropriate methodologies for selection. Participatory varietal selection (PVS) is one of the methodologies that might help the adoption of new varieties, as we try to show in this work. It incorporates all the actors in the potato value chain and includes special considerations of preferences by gender, as men and women often prioritise different criteria for selecting a new potato variety (De Haan et al. 2017), and these must be incorporated into breeding programs.

Participatory research integrates different stakeholder perspectives during the research process. In the case of selecting new potato varieties, researchers actively solicit input from farmer and consumer groups differentiated by gender to ensure that the varieties selected will meet the demands of local stakeholders by including traits that local farmers prioritise but researchers might overlook (Badstue et al. 2012). Decentralised, locally-responsive breeding and PVS enable the development and testing of candidate varieties under farm conditions. Moreover, these approaches can reduce timeframes for uptake by increasing the likelihood of acceptance through early exposure of farmers and consumers (men and women) to new materials, by involving them in the selection process (Klawitter et al. 2009) and by anticipating the need for adequate quantities of seed at the time of variety release. Participatory plant breeding methods show great promise in the development of new varieties that meet the technological needs of end users, mainly poor farmers who are not well integrated into market economies (Morris and Bellon 2004).

At CIP in Peru, we have three successful examples of potato variety selection using PVS. In the Altiplano region, PVS led to the selection of the variety INIA-317 
Altiplano for its resistance to the Andean weevil, tolerance to frost and drought, high yield, early maturity and high content of dry matter (Arcos et al. 2015). In Huancavelica, Junin and Huanuco, stakeholders identified resistance to LB, abundant foliage, tolerance to drought, and high yield, uniform size and tuber health at harvest as selection criteria for a new potato variety. The selected clones in these localities CIP396034.268, CIP393079.4 and CIP387096.2 have higher resistance to LB compared to the INIA-303 Canchan and Unica varieties which are susceptible to this disease (Zuñiga et al. 2018). In the community of Lircay in Huancavelica, stakeholders chose the variety INIA-321 Kawsay for its flowering and vigorous plants; they associate this trait with plants more resistant to LB and for its good yield and large tubers at harvest (Janampa 2012). The preferences of medium and large farmers are highly related to market preferences, but for small farmers they are related to quality for their own consumption, and resistance to abiotic or abiotic factors that allow them to obtain yields under their crop management conditions.

There are many illustrative examples of successful PVS around the world. In Bhutan, a farmer preference study found that farmers prefer varieties with red skin tubers (Bajgai et al. 2018). In Ethiopia, breeders developed new potato varieties with resistance to LB and to be sown in rainy seasons, but the farmers did not adopt them. Afterward, breeders used PVS and found high priority for six characteristics (drought tolerance, LB resistance, high yield, long shelf life, suitability for boiling and suitability for stew) that had been overlooked in the conventional potato breeding program (Tesfaye 2013; Abebe et al. 2013; Mudege et al. 2015; Semagn et al. 2015, 2017). In Syria, researchers found that farmers from marginal environments do not adopt higher yielding varieties if they have not participated in the development process (Southeast Asia Regional Initiatives for Community Empowerment 2007).

Climate change also affects the quality of the tubers. As temperatures and irregular rainfalls increase, the glycoalkaloid content is in risk of increase. High levels of glycoalkaloids can produce a bitter taste and can be unsafe for human consumption at levels exceeding $20 \mathrm{mg}$ per $100 \mathrm{~g}$ fresh weight of potatoes (Storey and Davies 1992; Ruprich et al. 2009). Hence, it is important to monitor the glycoalkaloid levels of tubers and evaluate the quality of tubers for consumption through organoleptic tests. These tests are included in the PVS methodology.

The main objective of this study was to use PVS to select LB-resistant clones with high potential to become varieties with high marketable tuber yields and other preferred agronomic traits. Successful application of PVS will enable greater adoption and dissemination of these varieties, ensuring their profitability, food safety, and improving the living conditions of small farmers.

\section{Materials and Methods}

\section{PVS Evaluation 2016-2017}

Thirty-six advanced potato clones from CIP's B3C3 population, belonging to the third cycle of recurrent phenotypic selection of the $\mathrm{B} 3$ population, derived from crossing the species Solanum tuberosum spp. andigena and tuberosum, S. demissum, S. bulbocastanum, S. acaule and S. phureja, were evaluated in Cajamarca, La Libertad 
and Huancavelica in Peru, using the PVS approach (De Haan et al. 2017). These clones have high levels of resistance to LB, high tuber yield and some clones displayed tolerance to heat, resistance to Potato Virus X (PVX), Potato Virus Y (PVY), good organoleptic quality and adaptation to mid-elevation and highlands. The clones were planted in two experiments of 18 clones each during 2016-2017. Two local susceptible varieties (INIA-303 Canchan, INIA-302 Amarilis and/or Yungay) were used as controls (Table 1).

Experiment 1 was planted in Chaquil, Cajamarca; in Canaypata, Huancavelica; and in Macullida, La Libertad. Experiment 2 was planted in Chucmar, Cajamarca and in La Soledad, La Libertad (Table 2).

In the two seasons (2016-2017 and 2017-2018), the experiments were sown using statistical design of randomised complete blocks (RCB) with 4 replications of 10 plants each. The distance between rows was $1.00 \mathrm{~m}$ and between plants $0.30 \mathrm{~m}$; the dose of fertilisation was 180-160-160 of NPK and the control of weeds and pests was carried out in a timely manner. Contact fungicides (Mancozeb) were applied before hilling to control LB, especially to protect susceptible controls. The harvest was at 120 days after planting.

\section{PVS Evaluation 2017-2018}

In 2017-2018, five selected potato clones from 2016-2017 were evaluated using PVS. These clones were selected based on preferences of farmers through PVS, high tuber yield, low glycoalkaloid content and good organoleptic quality (flavour) (Table 3).

The experiment included the five clones and two local varieties as controls (INIA303 Canchan, Yungay and/or INIA-302 Amarilis) and was planted in four locations: Chucmar in Cajamarca, La Aurorita and Arcopampa in La Libertad, and Cañaypata in Huancavelica (Table 2). Using RCB with four replications of 20 plants each, we employed PVS at flowering and harvest phenological phases of potato crop. In each phase, the selection criteria for a new variety were identified and prioritised and the clones were ranked, taking into account preferences by gender. To mark their preferences, each male farmer received six seeds of corn, whilst women were given six seeds of fava beans. Farmers proceeded to select three criteria and three clones of their preference, using three seeds for those they ranked first, two seeds for second and one seed for third. At the harvest, an organoleptic test of the clones was carried out to determine their appearance, flavour and texture using a panel of ten evaluators (five men and five women). Harvest took place 120 days after planting. The numbers and weights of marketable and non-marketable tubers per plot were recorded and the marketable and total yields per hectare were calculated.

\section{Total Glycoalkaloid Analysis}

At harvest, 15 tubers of each sample were collected and brought to the Quality and Nutrition Laboratory in CIP-Lima, Peru, for sample preparation and glycoalkaloid analysis. Freeze-dried and milled samples of each tuber were prepared and stored at $-20{ }^{\circ} \mathrm{C}$ until analysis. Total glycoalkaloid analysis was performed using the method described by Burgos et al. (2014) in which glycoalkaloid extraction was executed using methanol and chloroform before concentration at $60{ }^{\circ} \mathrm{C}$ in a rotary evaporator. The 


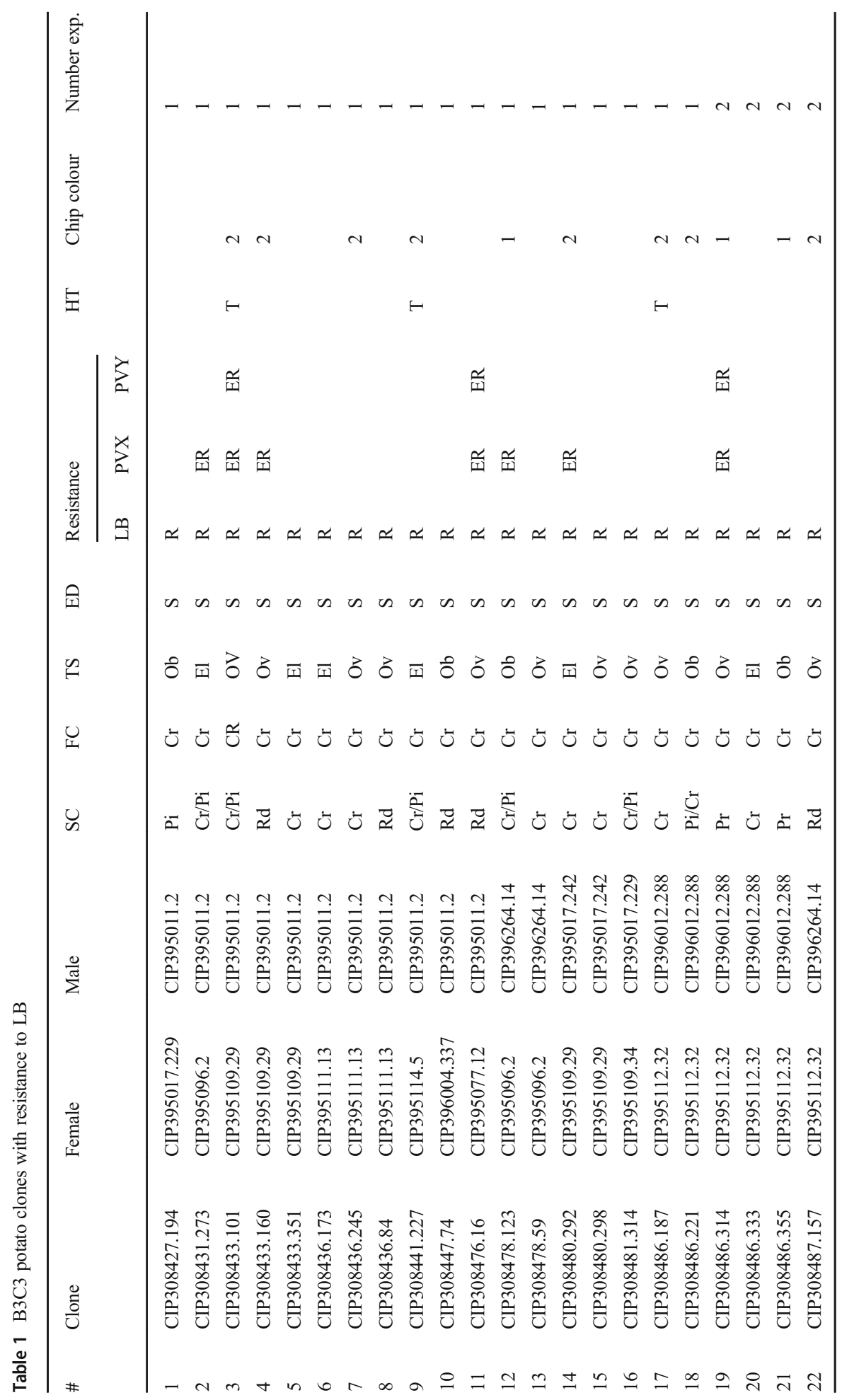




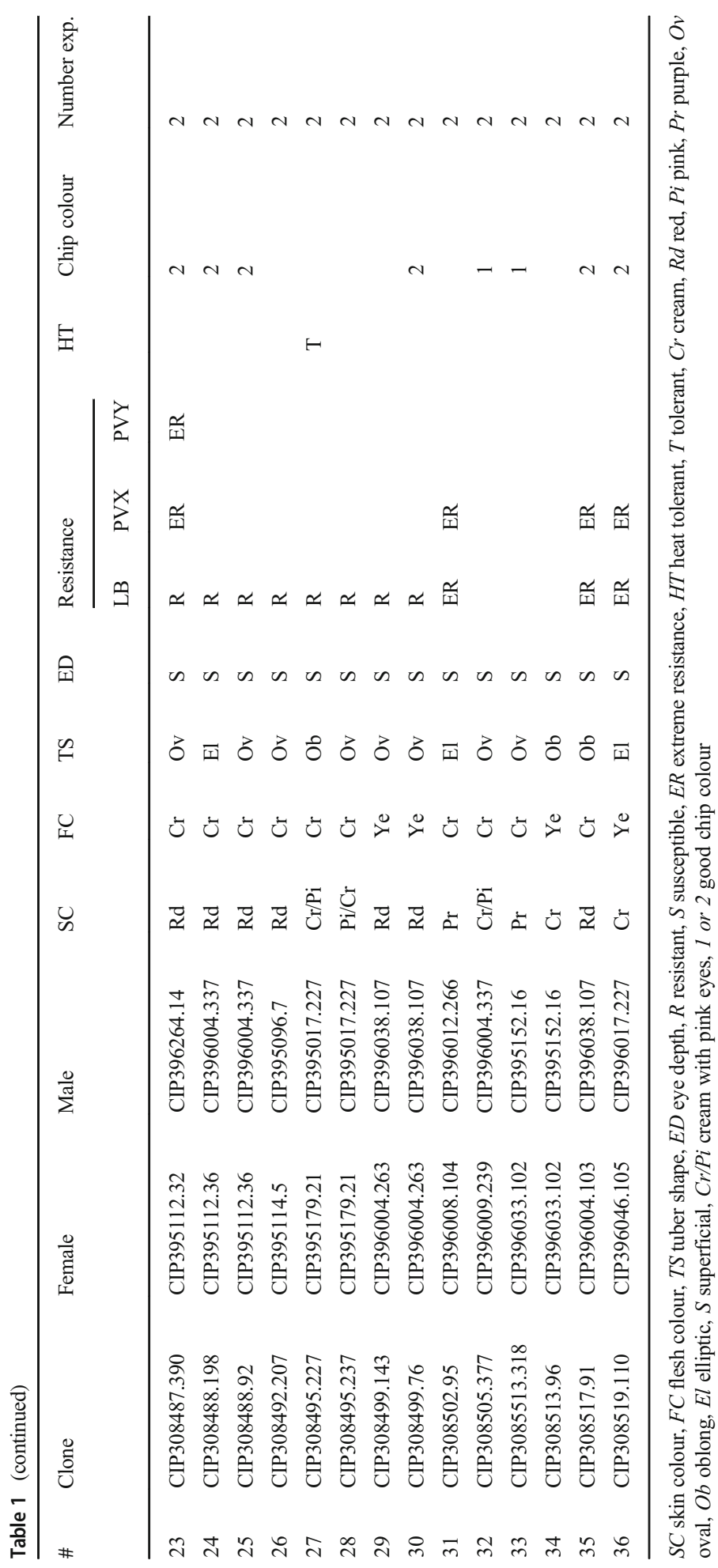




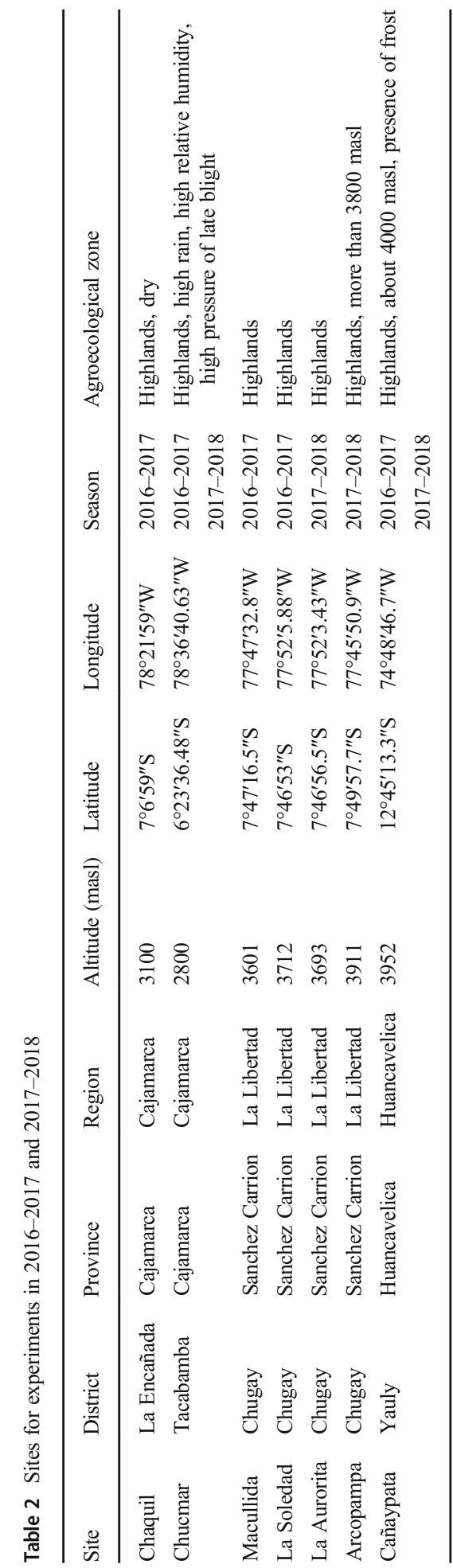


Table 3 Clones selected in 2016-2017 and tested in 2017-2018

\begin{tabular}{|c|c|c|c|c|c|c|c|c|c|c|}
\hline \multirow[t]{2}{*}{ \# } & \multirow[t]{2}{*}{ Clone } & \multicolumn{3}{|c|}{ Marketable tuber yield $\left(\mathrm{t} \mathrm{ha}^{-1}\right)$} & \multicolumn{3}{|c|}{$\begin{array}{l}\text { Total glycoalkaloid content } \\
\text { (mg/100 g fresh weight) }\end{array}$} & \multicolumn{3}{|c|}{ Flavour } \\
\hline & & CJA & LLB & HVA & CJA & LLB & HVA & CJA & LLB & HVA \\
\hline 1 & CIP308478.59 & 16.33 & 51.30 & 16.28 & 4.28 & 3.77 & 5.83 & 1 & 1 & 5 \\
\hline 2 & CIP308486.355 & 36.08 & 45.03 & & 7.04 & 12.93 & & 3 & 1 & \\
\hline 3 & CIP308488.198 & 36.21 & 43.57 & & 5.25 & 12.72 & & 1 & 1 & \\
\hline 4 & CIP308488.92 & 26.83 & 40.35 & & 3.77 & 6.78 & & 3 & 3 & \\
\hline 5 & CIP308495.227 & 27.26 & 53.15 & & 2.06 & 14.87 & & 3 & 3 & \\
\hline
\end{tabular}

1 = intermediate, 3 = good, 5 = excellent

CJA Cajamarca, LLB La Libertad, HVA Huancavelica

extract was transferred to a $2 \%$ acetic acid solution and then purified using ammonium hydroxide at $85{ }^{\circ} \mathrm{C}$ and ultracentrifugation at $27,000 \mathrm{rpm}$. The pellet was placed in reaction with $85 \%$ orthophosphoric acid and read at $408 \mathrm{~nm}$ in a spectrophotometer. The determination of total glycoalkaloids was achieved against a standard curve of $\alpha$ chaconine as reference. This parameter was used as a criterion to select clones that will continue to be evaluated next season. Only clones with a total glycoalkaloid concentration below the safe limit for human consumption $(20 \mathrm{mg} / 100 \mathrm{~g}$ fresh weight $)$ were selected.

\section{Statistical Analysis}

The information was stored in DATAVERSE, a database at CIP. Marketable tuber yield was analysed through linear mixed models using ASReml-R (Butler et al. 2017) and the e BLUP (Best Linear Unbiased Predictor) values were estimated (John 1989; Gilmour et al. 1997). Analysis of variance was performed using the software $\mathrm{R}$ and SAS v. 9.4, proc anova. Waller-Duncan means comparison test was used. The best clones were selected based on the PVS results, marketable tuber yield, low glycoalkaloid content and good organoleptic quality.

\section{Results and Discussion}

\section{PVS Evaluation 2016-2017}

\section{At Flowering}

The breakdown of participation by location and gender is provided in Table 4. In all sites, both men and women identified LB resistance as the most important selection criteria.

In Chaquil, both men and women also identified abundant foliage as the important criterion after LB resistance, followed by resistance to the Andean weevil and drought tolerance. This last criterion is important in Chaquil because rain has become erratic in 
Table 4 Number of PVS participants in the flowering and harvest stages

\begin{tabular}{|c|c|c|c|c|c|c|c|c|c|c|}
\hline \multirow[t]{2}{*}{ People } & \multicolumn{2}{|c|}{ Chaquil } & \multicolumn{2}{|c|}{ Chucmar } & \multicolumn{2}{|c|}{ Cañsaypata } & \multicolumn{2}{|c|}{ Soledad } & \multicolumn{2}{|c|}{ Macullida } \\
\hline & FS & HS & FS & HS & FS & HS & FS & HS & FS & HS \\
\hline Men & 18 & 12 & 17 & 16 & 12 & 12 & 7 & 11 & 5 & 5 \\
\hline Women & 10 & 16 & 1 & 12 & 12 & 13 & 7 & 12 & 5 & 5 \\
\hline Total & 28 & 28 & 18 & 28 & 24 & 25 & 14 & 23 & 10 & 10 \\
\hline
\end{tabular}

FS flowering stage, $H S$ harvest stage

the region due to climate change. Men identified the same criteria but in different order of importance (Table 5). The clones CIP308436.84, CIP308481.314 and CIP308436.173 were selected by men and women but with different order in the ranking of preference, and the clone CIP308478.59 was selected only by men (Table 6).

Table 5 Main selection criteria, at flowering and harvest stages, identified in PVS trials 2016-2017

\begin{tabular}{|c|c|c|c|c|c|c|c|c|c|c|c|}
\hline \multirow[t]{2}{*}{ Selection criteria } & \multirow[b]{2}{*}{ Stage } & \multicolumn{2}{|c|}{ Chaquil } & \multicolumn{2}{|c|}{ Chucmar } & \multicolumn{2}{|c|}{ Cañaypata } & \multicolumn{2}{|c|}{ Macullida } & \multicolumn{2}{|c|}{ Soledad } \\
\hline & & M & $\mathrm{W}$ & M & $\mathrm{W}$ & M & $\mathrm{W}$ & M & $\mathrm{W}$ & M & $\mathrm{W}$ \\
\hline Resistance to LB & Flowering & $1 *$ & 1 & 1 & 2 & 2 & 3 & 3 & 1 & 1 & 1 \\
\hline Resistance to Andean potato weevil & Flowering & 2 & 3 & & & 4 & 4 & 1 & 2 & & \\
\hline Abundant foliage & Flowering & 3 & 2 & & & 3 & 1 & & & & \\
\hline Drought tolerance & Flowering & 4 & 4 & & & & & & & & \\
\hline Vigorous plants & Flowering & & & & 1 & & & & & & \\
\hline Many stems & Flowering & & & & 2 & & & & & & \\
\hline Potato black leg resistant & Flowering & & & 2 & & & & & & & \\
\hline Abundant flowering & Flowering & & & 3 & & & & & & & \\
\hline Frost tolerance & Flowering & & & & & 1 & 1 & 3 & 3 & 2 & 2 \\
\hline Early varieties & Flowering & & & & & & 2 & 2 & & & \\
\hline Thick stems & Flowering & & & & & & & & & 3 & 3 \\
\hline High tuber yield & Harvest & 1 & 2 & 2 & 1 & 1 & 2 & 1 & 1 & 1 & 2 \\
\hline White/yellow tuber skin colour & Harvest & 2 & & & & & & 2 & 3 & 2 & \\
\hline Uniform tuber size & Harvest & & & 1 & & & & & & 3 & \\
\hline Red tuber skin colour & Harvest & & & 3 & 3 & & & & & & \\
\hline Superficial eyes & Harvest & 3 & 1 & & & & & 2 & 2 & & \\
\hline Many eyes & Harvest & & & & 2 & & & & & & \\
\hline Tubers shape elongated & Harvest & & & & & & 3 & & & & \\
\hline Tolerance to Andean potato weevil & Harvest & & & & & 3 & 1 & & & & 1 \\
\hline Wart resistance & Harvest & & & & & 2 & & & & & \\
\hline Floury and nutritious tubers & Harvest & & & & & & 4 & & & & 2 \\
\hline
\end{tabular}

$M$ men, $W$ women

*Order of merit 1 = excellent, 2 = very good, 3 = good, $4=$ moderate 
Table 6 Ranking of clones at flowering and harvest stages based on the selection criteria prioritised by farmers through the PVS, 2016-2017

\begin{tabular}{|c|c|c|c|c|c|c|c|c|c|c|c|c|c|c|c|c|c|c|}
\hline \multirow[t]{3}{*}{ Clones/varieties } & \multicolumn{9}{|c|}{ Flowering stage } & \multicolumn{9}{|c|}{ Harvest stage } \\
\hline & \multicolumn{2}{|c|}{ CHA } & \multicolumn{2}{|c|}{ CAN } & \multicolumn{2}{|c|}{ MAC } & \multicolumn{2}{|c|}{$\mathrm{CHU}$} & SOL & \multicolumn{2}{|c|}{ CHA } & \multicolumn{2}{|c|}{ CAN } & \multicolumn{2}{|c|}{ MAC } & $\mathrm{CHU}$ & \multicolumn{2}{|c|}{ SOL } \\
\hline & M & W & M & W & M & W & M & W $\mathrm{I}$ & $M \mathrm{~W}$ & $\mathrm{M}$ & W & M & W & M & $\mathrm{W} \mathrm{N}$ & $\mathrm{M} \mathrm{W}$ & M & W \\
\hline CIP308427.194 & & & $4^{*}$ & 4 & & & & & & & & & & & & & & \\
\hline CIP308433.101 & & & & & 2 & & & & & & & & & & & & & \\
\hline CIP308436.173 & 3 & 3 & & & 1 & 1 & & & & 3 & 3 & & & 3 & & & & \\
\hline CIP308436.245 & & & & & & 3 & & & & & & & & & & & & \\
\hline CIP308436.84 & 1 & 2 & 3 & 3 & & & & & & & 4 & 4 & 4 & & 4 & & & \\
\hline CIP308447.74 & & & & & & & & & & & & & & & & & & \\
\hline CIP308478.59 & 4 & & & & 3 & & & & & 1 & 2 & & & 1 & 2 & & & \\
\hline CIP308480.298 & & & 2 & & & & & & & & & & & & & & & \\
\hline CIP308481.314 & 2 & 1 & & & & & & & & 3 & & & & 2 & 1 & & & \\
\hline CIP308486.187 & & & & & & & & & & & & & & 4 & 3 & & & \\
\hline CIP308486.221 & & & & & & 2 & & & & 2 & 1 & 3 & 2 & & & & & \\
\hline CIP308486.314 & & & & & & & & & & & & & & & & 44 & & \\
\hline CIP308486.355 & & & & & & & 4 & 12 & 23 & & & & & & & 2 & & \\
\hline CIP308487.157 & & & & & & & & & & & & & & & & 11 & & \\
\hline CIP308487.157 & & & & & & & 11 & 1 & 1 & & & & & & & & & \\
\hline CIP308487.390 & & & & & & & 32 & 2 & & & & & & & & & & \\
\hline CIP308488.198 & & & & & & & 21 & 1 & & & & & & & & & & 2 \\
\hline CIP308488.92 & & & & & & & & & 3 & & & & & & & 23 & & 4 \\
\hline CIP308495.227 & & & & & & & & & & & & & & & & 3 & 3 & 5 \\
\hline CIP308499.143 & & & & & & & & & $4 \quad 2$ & & & & & & & & & \\
\hline CIP308502.95 & & & & & & & & & 1 & & & & & & & & & \\
\hline CIP308505.377 & & & & & & & & & 13 & & & & & & & & & \\
\hline CIP308513.318 & & & & & & & & & & & & & & & & & 2 & \\
\hline CIP308519.110 & & & & & & & & & & & & & & & & & & 1 \\
\hline Yungay & & & & 2 & & & & & & & & 2 & 3 & & & & 1 & 3 \\
\hline INIA-302 Amarilis & 3 & 4 & & & & & & & & 4 & 5 & & & & & & & \\
\hline INIA-303 Canchan & & & 1 & 1 & & & & & & & & 1 & 1 & & & & & \\
\hline
\end{tabular}

CHA Chaqui, CHU Chucmar, CAN Cañaypta, MAC Macullida, SOL La Soledad, $M$ men, $W$ women *Order of merit in ranking 1 = excellent, 2 = very good, 3 = good, 4 = moderate

In Chucmar, men also identified resistance to black leg (Erwinia spp.) as an important criterion because this location has high rain-induced humidity in soil, which favours the presence of other diseases as well as LB (Table 5). The clones CIP308487.157, CIP308488.198, CIP308487.390 and CIP308486.355 were selected by men and women, but in different order in the ranking of preference (Table 6).

In Cañaypata, located above 3500 masl, both men and women selected frost tolerance and abundant foliage as important criteria for the ability to recover after 
damage due to low temperatures. The varieties 'INIA-303 Canchan' and 'Yungay' were selected as best performing, followed by CIP308436.84 and CIP308427.194 (Table 6). The varieties were selected by farmers due to their superior adaptation to highlands more than 3500 masl.

In Macullida and Soledad, also above 3500 masl, both men and woman identified frost tolerance as an important criterion. In La Soledad, men and women selected the clones CIP308505.377, CIP308486.355 and CIP308499.143; the clone CIP308488.92 was selected only by men; and clones CIP308502.95 and CIP308487.157 were selected by women. In Macullida, the clone CIP308436.173 was selected by men and women, the clones CIP308433.101 and CIP308478.59 were selected by men and the clones CIP308436.245 and CIP308476.221 were selected by women (Table 6).

The ranking of the clones in this phenological phase was carried out based on the preferences of the farmers according to the selection criteria identified in each locality. The main criterion was resistance to LB in all localities (Tables 5 and 6).

\section{At Harvest}

The breakdown of participation by location and gender is provided in Table 4 . In all sites, both men and women identified tuber yield as the most important selection criteria.

In Chaquil, men said tubers should be white or yellow tuber skin colour with shallow eyes whilst women preferred that tubers should be resistant to weevil and mealy in addition to tuber yield (Table 5). Based on the selection criteria, most of the men selected clones CIP308436.173, CIP308848.314, CIP308478.59 and CIP308486.221, whilst most women selected CIP308436.173, CIP308486.221, CIP308447.74 and CIP308436.84. Both men and women selected the variety INIA302 Amarilis. The BLUPs for yield of marketable tubers in Chaquil were in the range 8.99 to $18.34 \mathrm{tha}^{-1}$, against the Yungay and Inia-302 Amarilis controls with 14.70 and $15.24 \mathrm{t} \mathrm{ha}^{-1}$, respectively (Tables 6 and 8).

In Chucmar men preferred that tubers should be uniform in size and women that tubers should have enough eyes; both men and women preferred red skin tuber colour (Table 5). Clones CIP308486.314, CIP308487.157 and CIP308488.92 were selected by men and women according to the selection criteria identified as important. Clone CIP308486.355 was selected only by the women and clone CIP308495.227 was selected only by the men. Marketable tuber yield was from 12.18 to $37.05 \mathrm{t} \mathrm{ha}^{-1}$ with the control varieties Yungay and INIA-302 Amarilis at 14.20 and $37.05 \mathrm{t} \mathrm{ha}^{-1}$ (Tables 6 and 8).

In Macullida both men and women identified that the tubers should have white or yellow tuber skin colour and superficial eyes, as important characteristics after yields. Men and women selected clones CIP308478.59, CIP308481.314 and CIP308486.187; the clone CIP308486.173 was selected by men; and CIP308436.84 selected by women. The yield of marketable tubers in Macullida was in the range of 18.06 to $51.30 \mathrm{t} \mathrm{ha}^{-1}$, against the Yungay and INIA-302 Amarilis controls with 49.41 and $45.86 \mathrm{t} \mathrm{ha}^{-1}$, respectively (Tables 6 and 8).

In Soledad, men preferred uniform tuber size and white or yellow tuber skin colour and women preferred tolerance to Andean Potato Weevil and floury and nutritious tubers. Men selected clone CIP308513.318 and variety Yungay; whilst women selected 
clones CIP308519.110, CIP308488.92 and CIP308488.198; and both men and women selected clone CIP308495.227. Marketable tuber yield was from 14.58 to $53.15 \mathrm{t} \mathrm{ha}^{-1}$ versus the control varieties Yungay and INIA-302 Amarilis with 39.17 and $47.30 \mathrm{t}$ $\mathrm{ha}^{-1}$, respectively (Tables 6 and 8).

In Cañaypata, men and women selected high tuber yield and tolerance to Andean potato weevil as the most important criteria. In addition men preferred wart resistance and women preferred tubers shape elongated, floury and nutritious tubers. Based on these criteria, both men and women selected the clones CIP308486.221 and CIP308436.84 and varieties INIA-303 Canchan and Yungay. The yield of marketable tubers was in the range 5.61 to $20.71 \mathrm{t} \mathrm{ha}^{-1}$, against the Yungay and INIA-303 Canchan controls with 19.20 and $33.61 \mathrm{t} \mathrm{ha}^{-1}$, respectively (Tables 5 and 6).

The combined analysis of variance for the marketable tuber yield per hectare, in experiments 1 and 2, reveals significant statistical differences for environments, clones and the interaction clones $\times$ environments $(P<0.01)$ (Table 7$)$. The marketable tuber yield of the clones was different across the localities. Some clones showed interaction with the localities; for example, in Chaquil the yields were low in relation to Chucmar, Macullida and Soledad, possibly because this locality had a period of drought caused by an abnormal rain regime during the development of the experiment. The same could have happened in Cañaypata because it is located near $4000 \mathrm{~m}$ above sea level, and probably the clones do not adapt to these altitudes. Some clones show yields acceptable in all localities and other clones had a significant $\mathrm{G} \times \mathrm{E}$ interaction such as the clones CIP308431.273, CIP30847.194 and CIP308505.377 and the Yungay variety, susceptible to late blight, that presented low yields in Chucmar, where the late blight pressure was very high as shown in Table 8.

The Waller-Duncan means comparison test $(P<0.01)$ is shown in Tables 8 and 9. In combined analysis, the BLUPs for marketable tuber yield values of the clones ranged from 12.40 to $40.55 \mathrm{t} \mathrm{ha}^{-1}$; in experiment 1, clones CIP308478.59, CIP308436.84 and CIP308433.351 yielded 27.97, 21.92 and $21.82 \mathrm{t} \mathrm{ha}^{-1}$, respectively; and in experiment 2, clones CIP308486.355, CIP308495.227 and CIP308488.198 yielded 40.55, 40.20 and $39.89 \mathrm{t} \mathrm{ha}^{-1}$, presenting the highest values of marketable tuber yield, respectively.

The content of glycoalkaloids in a sample of clones ranged from 0.84 to $63.84 \mathrm{mg} /$ $100 \mathrm{~g}$ fresh weight. The clones CIP308436.173 and CIP308481.314 exhibited high

Table 7 Combined analysis of variance for marketable tuber yield per hectare $\left(\mathrm{t} \mathrm{ha}^{-1}\right)$

\begin{tabular}{llclll}
\hline Source of variation & \multicolumn{2}{l}{ Exp. 1 } & & \multicolumn{2}{l}{ Exp. 2 } \\
\cline { 2 - 3 } \cline { 5 - 6 } & df & Mean square & & df & Mean square \\
\hline Environments & 2 & $8189.06^{* *}$ & & 1 & $5668.68^{* *}$ \\
Replication/environments & 9 & 34.38 & & 6 & 140.57 \\
Clones & 20 & $412.38^{* *}$ & & 19 & $571.84^{* *}$ \\
Clones $\times$ environments & 37 & $228.49^{* *}$ & & 19 & $193.64^{* *}$ \\
Pooled error & 171 & 36.50 & & 114 & 33.75 \\
C.V. \% & 30.25 & & & 20.68 & \\
\hline
\end{tabular}

$d f$ degrees of freedom

*** Statistically significant at $\alpha=0.01$ 
Table 8 Mean comparison amongst BLUPs for marketable tuber yield by locations

\begin{tabular}{|c|c|c|c|c|c|c|c|c|c|c|c|}
\hline \multicolumn{7}{|c|}{ Experiment $1\left(\mathrm{t} \mathrm{ha}^{-1}\right)$} & \multicolumn{5}{|c|}{ Experiment $2\left(\mathrm{t} \mathrm{ha}^{-1}\right)$} \\
\hline Clone & $\mathrm{CHA}$ & & MAC & & CAN & & Clone & SOL & & $\mathrm{CHU}$ & \\
\hline Amarilis & 15.24 & defg & 45.86 & $\mathrm{a}$ & 26.25 & $\mathrm{~b}$ & CIP308495.227 & 53.15 & $\mathrm{a}$ & 27.26 & cde \\
\hline Canchan & 17.07 & $\mathrm{~b}$ & 64.71 & $\mathrm{a}$ & 33.61 & a & Yungay & 39.17 & def & 14.20 & $\mathrm{i}$ \\
\hline CIP308478.59 & 16.33 & $\mathrm{bc}$ & 51.30 & $\mathrm{~b}$ & 16.28 & $\mathrm{c}$ & Amarilis & 47.30 & $\mathrm{ab}$ & 37.05 & $\mathrm{a}$ \\
\hline Yungay & 14.70 & cdefg & 49.41 & $\mathrm{~b}$ & 19.20 & $\mathrm{~b}$ & CIP308486.355 & 45.03 & $a b c$ & 36.08 & $\mathrm{ab}$ \\
\hline CIP308486.187 & 13.85 & defg & 36.64 & $\mathrm{c}$ & 11.81 & efg & CIP308513.318 & 44.85 & bcd & 26.29 & cdef \\
\hline CIP308436.173 & 17.85 & $\mathrm{~b}$ & 34.83 & $\mathrm{c}$ & 11.78 & efg & CIP308486.333 & 44.08 & bcd & 29.36 & $\mathrm{~cd}$ \\
\hline CIP308433.160 & 10.95 & ghi & 34.78 & $\mathrm{c}$ & 10.21 & fgh & CIP308488.198 & 43.57 & bcde & 36.21 & $a b$ \\
\hline CIP308433.351 & 16.22 & bcde & 34.21 & $\mathrm{c}$ & 15.03 & cde & CIP308487.157 & 40.88 & bcde & 30.85 & $\mathrm{bc}$ \\
\hline CIP308481.314 & 16.58 & bcdef & 32.03 & $\mathrm{~cd}$ & 9.60 & fgh & CIP308488.92 & 40.35 & cdef & 26.83 & cde \\
\hline CIP308436.84 & 17.71 & $\mathrm{~b}$ & 31.62 & $\mathrm{~cd}$ & 16.44 & $\mathrm{c}$ & CIP308486.314 & 38.51 & def & 28.88 & $\mathrm{~cd}$ \\
\hline CIP308486.221 & 15.51 & cdefg & 31.42 & $\mathrm{~cd}$ & 13.96 & cdef & CIP308505.377 & 36.41 & efg & 14.23 & hi \\
\hline CIP308480.298 & 16.41 & bcd & 31.29 & $\mathrm{~cd}$ & 13.56 & def & CIP308495.237 & 36.36 & efg & 21.47 & efg \\
\hline CIP308436.245 & 16.49 & bcd & 31.04 & $\mathrm{~cd}$ & 13.77 & def & CIP308487.390 & 34.19 & fgh & 23.79 & defg \\
\hline CIP308476.16 & 18.34 & $\mathrm{a}$ & 26.85 & de & 10.31 & efg & CIP308519.110 & 32.70 & fgh & 19.75 & efg \\
\hline CIP308447.74 & 12.67 & efgh & 26.80 & de & 5.61 & $\mathrm{~h}$ & CIP308513.96 & 28.49 & ghi & 17.27 & ghi \\
\hline CIP308480.292 & 17.69 & $\mathrm{~b}$ & 25.28 & de & 10.09 & efg & CIP308492.207 & 26.18 & hi & 22.16 & efg \\
\hline CIP308427.194 & 9.40 & hi & 23.93 & def & 20.71 & $\mathrm{~b}$ & CIP308502.95 & 25.86 & hi & 18.75 & fgh \\
\hline CIP308431.273 & 9.87 & hi & 20.88 & ef & 6.66 & $\mathrm{gh}$ & CIP308499.14 & 22.18 & $\mathrm{ij}$ & 23.26 & defg \\
\hline CIP308478.123 & 8.99 & hi & 20.17 & ef & 12.26 & def & CIP308517.91 & 19.79 & $\mathrm{ij}$ & 15.57 & ghi \\
\hline CIP308433.101 & 14.60 & cdefg & 19.82 & ef & 9.77 & fgh & CIP308499.76 & 14.68 & $\mathrm{j}$ & 12.18 & $\mathrm{i}$ \\
\hline CIP308441.227 & 9.08 & hi & 18.06 & efg & 10.06 & efg & & & & & \\
\hline
\end{tabular}

*Clones and varieties with the same letter are not statistically different by Waller-Duncan test $(P>0.05)$

glycoalkaloid content, exceeding the maximum allowed value of $20 \mathrm{mg} / 100 \mathrm{~g}$ fresh weight (Table 10).

The results of the organoleptic test carried out within the PVS methodology show us that there are clones that, according to the preference of farmers, have a good taste (grade 3). The clone CIP308478.59 was the only one that had a qualification of excellent (grade 5), being selected for the second phase of the study (Table 11).

In all localities, the most important selection criteria preferred by farmers for the selection of clones as future varieties, and providing very valuable information for breeders, were resistance to late blight and high tuber yield.

The clones CIP308478.59, CIP308486.355, CIP308488.198, CIP308488.92 and CIP308495.227 were selected, based on the results of the participatory evaluation (PVS), where they should have been selected at flowering and/or harvest by men and/or women to meet the most important criteria preferred by farmers. Good organoleptic quality, marketable tuber yield and low glycoalkaloid content (less than $20 \mathrm{mg}$ / $100 \mathrm{~g}$ fresh weight) were also taken into account (Table 12).

These clones were evaluated again in the 2017-2018 season, to select clones with high potential to become varieties. 
Table 9 Mean comparison amongst BLUPs for marketable tuber yield in experiment 1 averaged over three locations and in experiment 2 over two locations

\begin{tabular}{|c|c|c|c|c|c|}
\hline \multicolumn{3}{|l|}{ Experiment 1} & \multicolumn{3}{|l|}{ Experiment 2} \\
\hline Clone/variety & $\mathrm{tha}^{-1}$ & Mean comparison & Clone/variety & $\mathrm{t} \mathrm{ha}^{-1}$ & Mean comparison \\
\hline INIA-303 Canchan & 38.46 & a & AMARILIS & 42.12 & $\mathrm{a}$ \\
\hline INIA-302 Amarilis & 37.18 & $\mathrm{a}$ & CIP308486.355 & 40.55 & $\mathrm{a}$ \\
\hline CIP308478.59 & 27.97 & $\mathrm{~b}$ & CIP308495.227 & 40.20 & $\mathrm{a}$ \\
\hline YUNGAY & 27.79 & $\mathrm{bc}$ & CIP308488.198 & 39.89 & $\mathrm{a}$ \\
\hline CIP308436.84 & 21.92 & bcd & CIP308486.333 & 36.72 & $\mathrm{ab}$ \\
\hline CIP308433.351 & 21.82 & bed & CIP308487.157 & 35.87 & $\mathrm{ab}$ \\
\hline CIP308436.173 & 21.49 & bcd & CIP308513.318 & 35.57 & $\mathrm{bc}$ \\
\hline CIP308486.187 & 20.77 & bed & CIP308486.314 & 33.69 & bcd \\
\hline CIP308436.245 & 20.43 & def & CIP308488.92 & 33.59 & bcde \\
\hline CIP308480.298 & 20.42 & defg & YUNGAY & 30.79 & cdef \\
\hline CIP308486.221 & 20.30 & defg & CIP308487.390 & 28.99 & defg \\
\hline CIP308481.314 & 19.43 & defg & CIP308495.237 & 28.91 & efgh \\
\hline CIP308433.160 & 18.65 & defgh & CIP308519.110 & 26.22 & fghi \\
\hline CIP308476.16 & 18.50 & efgh & CIP308505.377 & 25.32 & ghi \\
\hline CIP308427.194 & 18.02 & fghi & CIP308492.207 & 24.17 & ghi \\
\hline CIP308480.292 & 17.65 & fghij & CIP308513.96 & 22.88 & hij \\
\hline CIP308447.74 & 15.03 & ghij & CIP308499.143 & 22.72 & hij \\
\hline CIP308433.101 & 14.73 & hij & CIP308502.95 & 22.31 & $\mathrm{ij}$ \\
\hline CIP308478.123 & 13.80 & ij & CIP308517.91 & 17.68 & $\mathrm{j}$ \\
\hline CIP308431.273 & 12.47 & ij & CIP308499.76 & 13.43 & $\mathrm{k}$ \\
\hline CIP308441.227 & 12.40 & $\mathrm{j}$ & & & \\
\hline
\end{tabular}

*Clones and varieties with the same letter are not statistically different by Waller-Duncan test $(P>0.05)$

\section{PVS Evaluation 2017-2018}

\section{At Flowering}

Twenty-eight farmers (16 men and 12 women) participated in Chucmar at flowering, 16 farmers ( 8 men and 8 women) in La Aurorita, 11 farmers ( 5 men and 6 women) in Arcopampa and 25 farmers (11 men and 14 women) in Canaypata, Huancavelica.

Men and women in Chucmar, Aurorita and Arcopampa, and only men in Cañaypta, identified resistance to LB as the most important criteria of selection, which aligns with the results obtained in previous studies in Peru (Janampa 2012; Zuñiga et al. 2018). In Chucmar, both men and women identified that plants should have many vigorous stems, but women added that new varieties should have resistance to Andean potato weevil. In Aurorita and Arcopampa, both men and women identified tall plants and compact foliage, whilst in Arcopampa they identified resistance to Andean potato weevil. In Cañaypata, men preferred small leaves and hailstorm-tolerant varieties whilst women selected frost tolerance, small leaves and tall plants as the most important 
Table 10 Glycoalkaloid content in B3C3 clones 2016-2017

\begin{tabular}{|c|c|c|c|c|c|}
\hline \multirow[t]{2}{*}{ Clones/variety } & \multicolumn{5}{|c|}{ Glycoalkaloid content (mg/100 g fresh weight) } \\
\hline & Chaquil & Macullida & Cañaypata & Chucmar & Soledad \\
\hline CIP308427.194 & 6.53 & 2.57 & 6.82 & & \\
\hline CIP308433.101 & 3.38 & 3.42 & 3.20 & & \\
\hline CIP308433.160 & 6.05 & 6.48 & 5.56 & & \\
\hline CIP308433.351 & 8.72 & 6.88 & 7.28 & & \\
\hline CIP308436.173 & 27.74 & 17.01 & 23.97 & & \\
\hline CIP308436.84 & 19.73 & 8.62 & 13.28 & & \\
\hline CIP308478.123 & 1.26 & 0.84 & 1.45 & & \\
\hline CIP308478.59 & 4.28 & 3.77 & 5.83 & & \\
\hline CIP308480.292 & 7.71 & 3.20 & 5.79 & & \\
\hline CIP308481.314 & 60.07 & 63.84 & 63.00 & & \\
\hline CIP308486.187 & 6.19 & 2.52 & 5.66 & & \\
\hline CIP308486.221 & 16.85 & 10.39 & 15.28 & & \\
\hline CIP308486.314 & & & & 2.03 & 5.74 \\
\hline CIP308486.333 & & & & 6.99 & 16.83 \\
\hline CIP308486.355 & & & & 7.04 & 12.93 \\
\hline CIP308487.157 & & & & 3.70 & 6.16 \\
\hline CIP308488.198 & & & & 5.25 & 12.72 \\
\hline CIP308488.92 & & & & 3.77 & 6.78 \\
\hline CIP308495.227 & & & & 2.06 & 14.87 \\
\hline CIP308502.95 & & & & 11.16 & 7.91 \\
\hline INIA-302 Amarilis & 4.40 & 2.70 & & 1.22 & 3.34 \\
\hline INIA-303 Canchan & & & 7.87 & & \\
\hline Yungay & 6.28 & 1.97 & 5.75 & 2.14 & 4.39 \\
\hline
\end{tabular}

criteria in the flowering phase. The selection of frost tolerance as an important criterion aligns with results from Arcos et al. (2015) which also came from a site located above 3500 masl (Table 13).

\section{At Harvest}

In Chucmar, 24 farmers (16 men and 8 women) participated in PVS at harvest. Both men and women identified resistance to LB, good yield and good quality for market as the most important criteria. Women also preferred tubers with good taste. On this basis, clones CIP308488.92, CIP308495.227 and CIP308478.59 were selected by both men and women (Table 14). Marketable tuber yield of the three selected clones was higher than the two control varieties, INIA-302 Amarilis and Yungay, which were both affected almost $100 \%$ by LB. The clones CIP308495.227, CIP308488.92 and CIP308478.59 yielded $31.52 \mathrm{t} \mathrm{ha}^{-1}, 35.16 \mathrm{t} \mathrm{ha}^{-1}$ and $33.24 \mathrm{t} \mathrm{ha}^{-1}$, respectively, against Yungay and INIA-302 Amarilis at 5.00 and $8.23 \mathrm{t} \mathrm{ha}^{-1}$, respectively (Table 16). The organoleptic test showed that the clones CIP308495.227 and 
Table 11 Organoleptic test in B3C3 clones by locality at harvest with PVS methodology

\begin{tabular}{|c|c|c|c|c|c|c|}
\hline \multirow[t]{2}{*}{ Clone } & \multicolumn{6}{|l|}{ Flavour } \\
\hline & Macullida & Soledad & Chucmar & Chaquil & Cañaypata & Experiment \\
\hline CIP308427.194 & 1 & & & 3 & 3 & 1 \\
\hline CIP308431.273 & 1 & & & 1 & 3 & 1 \\
\hline CIP308433.101 & 1 & & & 3 & 3 & 1 \\
\hline CIP308433.160 & 1 & & & 1 & 3 & 1 \\
\hline CIP308433.351 & 1 & & & 1 & 3 & 1 \\
\hline CIP308436.173 & 1 & & & 1 & 1 & 1 \\
\hline CIP308436.245 & 1 & & & 1 & 1 & 1 \\
\hline CIP308436.84 & 1 & & & 3 & 3 & 1 \\
\hline CIP308441.227 & 3 & & & 1 & 3 & 1 \\
\hline CIP308447.74 & 1 & & & 1 & 3 & 1 \\
\hline CIP308476.16 & 1 & & & 1 & 3 & 1 \\
\hline CIP308478.123 & 3 & & & 3 & 3 & 1 \\
\hline CIP308478.59 & 1 & & & 1 & 5 & 1 \\
\hline CIP308480.292 & 1 & & & 1 & 3 & 1 \\
\hline CIP308480.298 & 1 & & & 1 & 1 & 1 \\
\hline CIP308481.314 & 1 & & & 3 & 1 & 1 \\
\hline CIP308486.187 & 1 & & & 1 & 3 & 1 \\
\hline CIP308486.221 & 3 & & & 3 & 1 & 1 \\
\hline CIP308486.314 & & 1 & 1 & & & 2 \\
\hline CIP308486.333 & & 3 & 3 & & & 2 \\
\hline CIP308486.355 & & 1 & 3 & & & 2 \\
\hline CIP308487.157 & & 3 & 1 & & & 2 \\
\hline CIP308487.390 & & 3 & 1 & & & 2 \\
\hline CIP308488.198 & & 1 & 1 & & & 2 \\
\hline CIP308488.92 & & 3 & 3 & & & 2 \\
\hline CIP308492.207 & & 1 & 1 & & & 2 \\
\hline CIP308495.227 & & 3 & 3 & & & 2 \\
\hline CIP308495.237 & & 1 & 3 & & & 2 \\
\hline CIP308499.143 & & 1 & 1 & & & 2 \\
\hline CIP308499.76 & & 3 & 3 & & & 2 \\
\hline CIP308502.95 & & 1 & 5 & & & 2 \\
\hline CIP308505.377 & & 1 & 1 & & & 2 \\
\hline CIP308513.318 & & 1 & 3 & & & 2 \\
\hline CIP308513.96 & & 3 & 1 & & & 2 \\
\hline CIP308517.91 & & 3 & 1 & & & 2 \\
\hline CIP308519.110 & & 1 & 1 & & & 2 \\
\hline
\end{tabular}

1 = intermediate, $3=$ good, 5 = excellent 


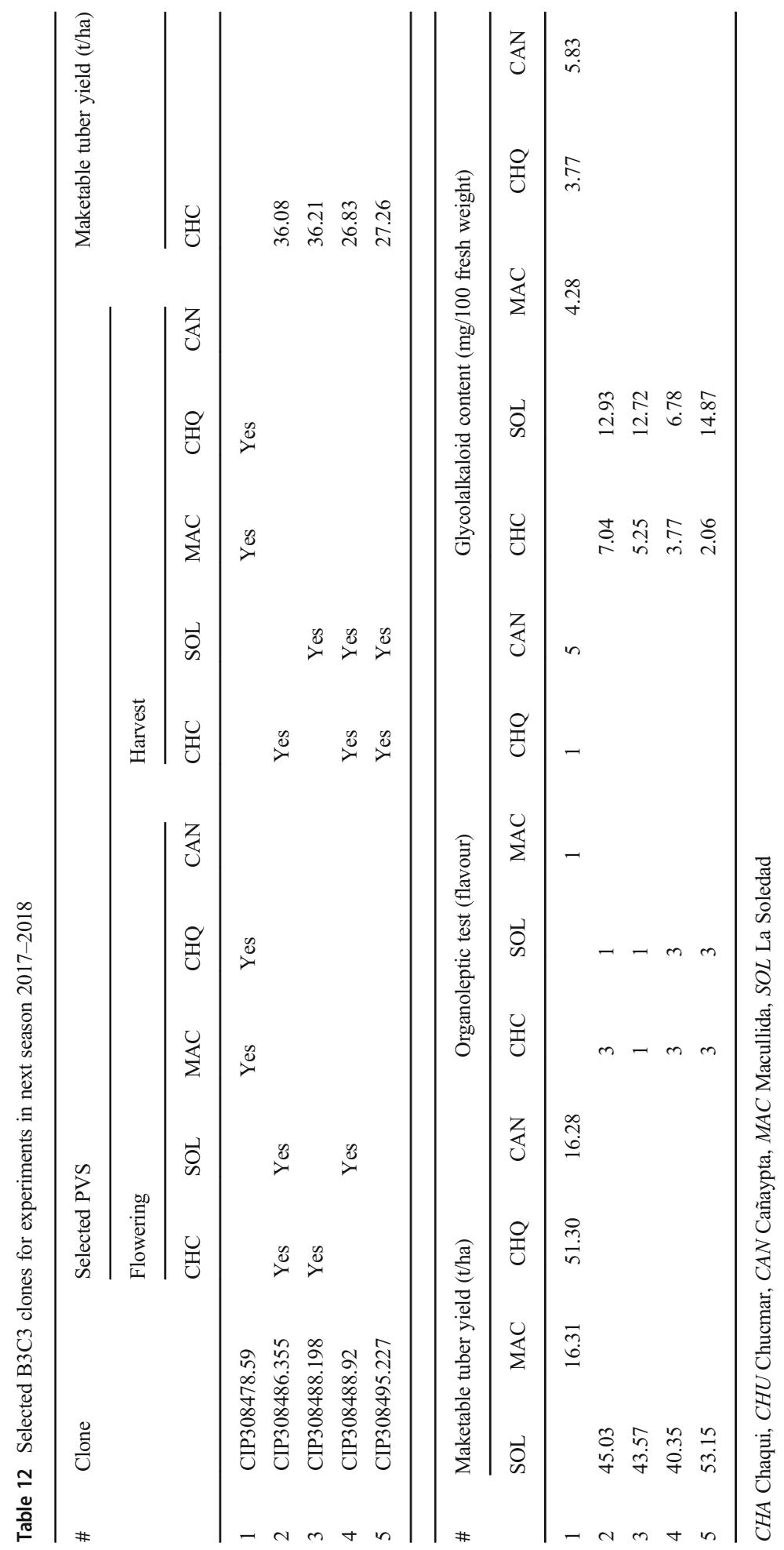


Table 13 Main selection criteria identified in PVS trials at flowering and harvest stages, 2017-2018

\begin{tabular}{|c|c|c|c|c|c|c|c|c|c|c|}
\hline \multirow[t]{2}{*}{$\#$} & \multirow[t]{2}{*}{ Selection criteria } & \multirow[t]{2}{*}{ Stage } & \multicolumn{2}{|c|}{$\begin{array}{l}\text { Chucmar } \\
\text { Cajamarca }\end{array}$} & \multicolumn{2}{|c|}{$\begin{array}{l}\text { Aurorita La } \\
\text { Libertad }\end{array}$} & \multicolumn{2}{|c|}{$\begin{array}{l}\text { Arcopampa La } \\
\text { Libertad }\end{array}$} & \multicolumn{2}{|c|}{$\begin{array}{l}\text { Cañaypata } \\
\text { Huancavelica }\end{array}$} \\
\hline & & & $\mathrm{M}$ & W & M & $\mathrm{W}$ & M & $\mathrm{W}$ & $\mathrm{M}$ & $\mathrm{W}$ \\
\hline 1 & Resistance to LB & Flowering & $1^{*}$ & 2 & 1 & 1 & 1 & 1 & 1 & \\
\hline 2 & Many stems & Flowering & 2 & & & & & & & \\
\hline 3 & Broad leaved & Flowering & & & & & & & & \\
\hline 4 & Tall plants & Flowering & & & 2 & 2 & 2 & 2 & & 3 \\
\hline 5 & Compact foliage & Flowering & & & & 3 & 3 & 3 & & \\
\hline 6 & Medium size plants & Flowering & & & & & & & & \\
\hline 7 & Many flowers & Flowering & & & 3 & 3 & & & & \\
\hline 8 & Resistant to the weevil & Flowering & & 3 & & & 3 & 3 & & \\
\hline 9 & Vigorous stem & Flowering & 3 & 1 & & & & & & \\
\hline 10 & Small leaves & Flowering & & & & & & & 2 & 1 \\
\hline 11 & Tolerant to hailstorm & Flowering & & & & & & & 3 & \\
\hline 12 & Frost tolerant & Flowering & & & & & & & & 2 \\
\hline 13 & Dry leaves & Flowering & & & & & & & & 3 \\
\hline 1 & Good yield & Harvest & 2 & 2 & 3 & 3 & 2 & 1 & 1 & 1 \\
\hline 2 & Big tubers & Harvest & & & 2 & 2 & 3 & 2 & 2 & 4 \\
\hline 3 & Resistance to LB & Harvest & 1 & 1 & 1 & 1 & 1 & 3 & & 2 \\
\hline 4 & Good quality for market & Harvest & 3 & 3 & & & & & & \\
\hline 5 & Tuber of two colours & Harvest & & & & & & & 3 & \\
\hline 6 & Resistant to other disease & Harvest & & & & & 3 & 1 & & \\
\hline 7 & Yellow flesh colour & Harvest & & 2 & & & & & & \\
\hline 8 & Palatability & Harvest & & 3 & & & & & & \\
\hline 9 & Resistant to the weevil & Harvest & 3 & & & & & & & 3 \\
\hline
\end{tabular}

*Order of merit 1 = excellent, 2 = very good, 3 = good, 4 = moderate

CIP308478.59 had good flavour on par with INIA-302 Amarilis and Yungay. The glycoalkaloid content was low, ranging from 2.01 up to $5.35 \mathrm{mg} / 100 \mathrm{~g}$ of fresh weight (FW), less than the limit value of $20 \mathrm{mg} / 100 \mathrm{~g} \mathrm{FW}$ (Table 14).

In La Aurorita, 16 farmers ( 7 men and 9 women) participated in PVS during harvest. Both men and women identified resistance to LB, big tubers and high tuber yield as the most important selection criteria. Men selected clones CIP308495.227, CIP308488.92 and CIP308488.198 with $34.09 \mathrm{t} \mathrm{ha}^{-1}, 37.26 \mathrm{t} \mathrm{ha}^{-1}$ and $38.34 \mathrm{t} \mathrm{ha}^{-1}$, respectively, and women also selected clone CIP308486.355 with $35.57 \mathrm{t} \mathrm{ha}^{-1}$. Marketable tuber yield of these clones was higher than controls INIA-303 Canchan and INIA-302 Amarilis with 25.46 and $21.02 \mathrm{t} \mathrm{ha}^{-1}$, respectively. The yield of INIA-302 Amarilis grown in La Aurorita was higher than in Chucmar because the LB pressure in this site was lower (Table 16). The organoleptic test, carried out by the farmers, showed that clones CIP308488.92 and CIP388495.227 had good flavour on par with INIA-303 Canchan. The content of glycoalkaloids was low and ranged from 3.59 to $6.67 \mathrm{mg} / 100 \mathrm{~g} \mathrm{FW}$, less than the limit value of $20 \mathrm{mg} / 100 \mathrm{~g} \mathrm{FW}$ (Table 14). 


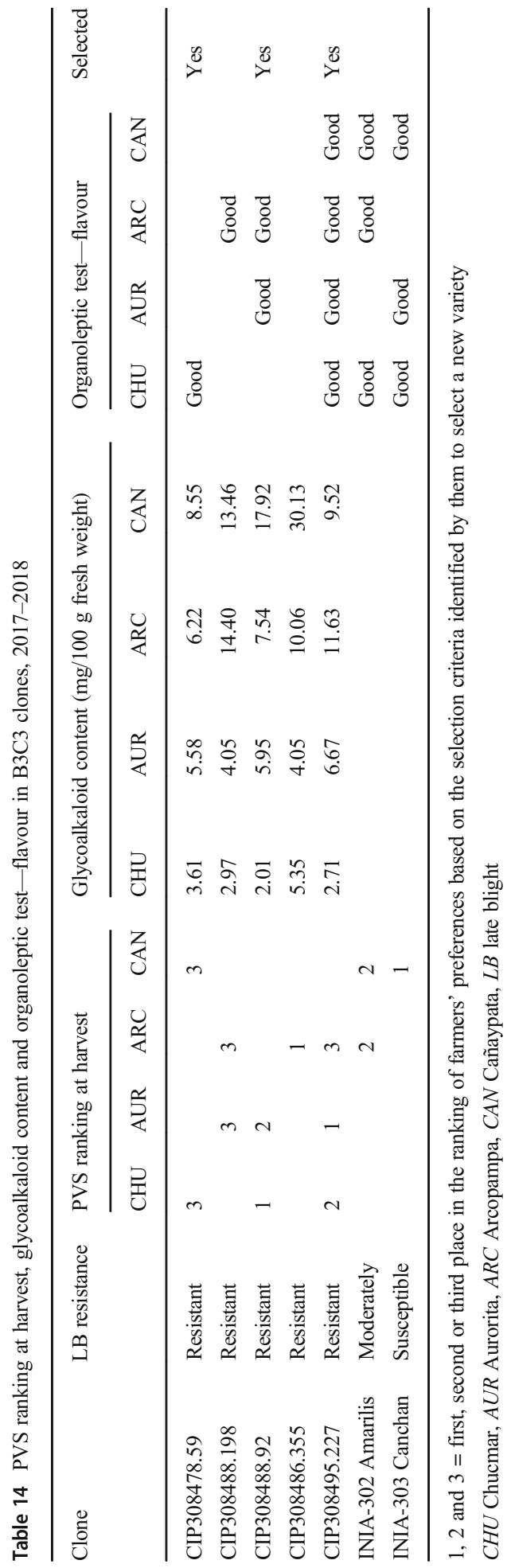


In Arcopampa, 14 farmers (8 men and 6 women) participated in PVS during harvest. Both men and women identified resistance to LB, big tubers and high tuber yield as the most important traits (Table 13). Men identified clones CIP308486.355, CIP308495.227 and CIP308488.198 with 18.95, 19.51 and $18.51 \mathrm{t} \mathrm{ha}^{-1}$, respectively, and women selected clone CIP308478.59 (with $19.54 \mathrm{t} \mathrm{ha}^{-1}$ ) and the varieties INIA303 Canchan and INIA-302 Amarilis. Marketable tuber yield of the selected clones was less than Amarilis and Canchan (21.66 and $20.94 \mathrm{t} \mathrm{ha}^{-1}$, respectively). The yields of the selected clones were lower, probably due to the high altitude of this place, and the clones did not adapt to these conditions (Table 16). The organoleptic test carried out by the farmers shows that clones CIP308495.227, CIP308488.198 and CIP308488.92 had a good flavour on par with INIA-303 Canchan. The content of glycoalkaloids was low and ranged from 6.22 to $14.40 \mathrm{mg} / 100 \mathrm{~g} \mathrm{FW}$, less than the limit value of $20 \mathrm{mg} / 100 \mathrm{~g}$ FW (Table 14).

In Cañaypata, 29 farmers (14 men and 15 women) participated in PVS during harvest. Men identified high tuber yield, big tubers and tubers with two skin colour as most important criteria. Women chose high yield, resistance to LB and Andean potato weevil as the most important criteria (Table 13). Men and women identified varieties Yungay and INIA-303 Canchan and the clone CIP308478.59 as best, with $31.45,20.57$ and $11.63 \mathrm{t} \mathrm{ha}^{-1}$, respectively (Table 16). The organoleptic test, carried out by the farmers, showed that clone CIP308495.227 had good flavour on par with INIA-303 Canchan and Yungay (Table 14). The yields of the selected clones were low, likely due to the fact that the clones were not adapted to altitudes above 3700 masl and because the experiment was affected by frost twice during the growing period. The content of glycoalkaloids ranged from 8.55 to $30.13 \mathrm{mg} / 100 \mathrm{~g} \mathrm{FW}$ (Table 14). The clone CIP308486.355 showed a very high level of glycoalkaloids (30.13 mg /100 g FW) in Cañaypata, almost 50\% above the safe limit in tubers. This high value is likely due to the fact that this clone was more susceptible to frost and the high content of glycoalkaloids were produced as a reaction to the stress produced by low temperatures during the experiment (Table 14).

In all locations, good tuber yield was identified as an important selection criterion, which matches the finding of other research in Peru (Janampa 2012; Arcos et al. 2015; Zuñiga et al. 2018), confirming that potato varieties adapted to mid-elevation and highland environments should be resistant to LB and offer good tuber yield (Table 13). These criteria were used by farmers in the PVS methodology to identify the three best clones for their preference.

Clones CIP308495.227 and CIP308488.92 were selected in Chugmar and Aurorita, but not in Arcopampa and Cañaypata. The last two locations are above 3900 masl and the clones are better adapted to lower altitudes. The clone CIP308478.59 was selected in Chugmar and Canaypata, showing a wider adaptation to low and high altitudes (Table 14). These results are consistent with Semagn et al. (2017). Overall, our findings indicate that no variety possesses all desirable characteristics and that there is a need for selecting varieties adapted to different agroecologies and growing seasons. Further studies should take farmer interests into account for a highly heterozygous, clonally propagated crop like potato to be accepted by farmers. The differences in adaptation are probably the result of the population improvement that was carried out in CIP, where the aim is to maintain a wide gene and genotypic variability. 
The combined analysis of variance for marketable tuber yield per hectare shows statistically significant differences $(P<0.01)$ for the environments, clones and interaction clones $\times$ environments (Table 15 ). The coefficient of variation at $30.79 \%$ was within the acceptable range.

The clone $\times$ environment interaction was probably due to the contrasting environments where the experiments were planted. In Chucmar and Aurorita, the marketable yield was higher than in Arcopampa and Cañaypata, which are located at altitudes greater than 3700 masl with the presence of frost, and most clones do not adapt well to these conditions. Another factor was the high pressure of late blight in Chucmar where Yungay and Amarilis were strongly affected by this disease, resulting in very low yields, compared to the locations where late blight pressure was lower (Table 16).

After analysing the results of PVS and tuber yields using mixed models and BLUPs, and considering good organoleptic quality and low glycoalkaloid content, three clones were selected, CIP308488.92, CIP308495.227 and CIP308478.59 with 24.75, 24.16 and $24.68 \mathrm{t} \mathrm{ha}^{-1}$, respectively.

The clones CIP308488.92 and CIP308495.227 were selected based on the preference of the farmers during the participatory varietal selection (PVS) at harvest in Chucmar and Aurorita, their low content of glycoalkaloids, good quality of flavour in the organoleptic test in Arcopampa and Aurorita for the first clone and across all locations for the second clone, combined with high average yields from all locations. These clones are recommended as promising for new varieties at midelevation or in environments below 3500 masl in highlands in sub-Saharan Africa (Rwanda, Kenya, Ethiopia), South Asia (Nepal, Bhutan) and in the Andean zone of Latin America and may show good adaptation where there is no frost and the main problem is LB (Table 14). However, more trials are needed before recommendation for any of these clones to be registered as new varieties.

The clone CIP308478.59 was selected for its wider adaptation. It was selected by farmers through PVS in two contrasting environments Chucmar and Cañaypata. Its good taste was also considered in the organoleptic test in Chucmar and its low content of glycoalkaloids. This clone could be an alternative for environments located above 3700 masl, in the Andean zone of Latin America. However, there is a need to evaluate a new set of LB-resistant clones that also show tolerance to frost to have a better pool of clones for farmer selection.

Table 15 Combined analysis of variance for marketable tuber yield ( $\left.\mathrm{t} \mathrm{ha} \mathrm{a}^{-1}\right)$

\begin{tabular}{llc}
\hline Source of variation & df & Mean square \\
\hline Environments & 3 & $1978.46^{* * *}$ \\
Replications/environments & 12 & 15.46 \\
Clones & 7 & $187.99^{* *}$ \\
Clones $\times$ environments & 17 & $319.86^{* *}$ \\
Error & 72 & 28.35 \\
\hline
\end{tabular}

C.V. $=30.79 \%$

**Statistically significant at $P<0.01 d f=$ degrees of freedom 
Table 16 Mean comparison amongst BLUPs for marketable tuber yield

\begin{tabular}{llllll}
\hline \multirow{2}{*}{ Clone } & \multicolumn{2}{l}{ BLUP marketable tuber yield $\left(\mathrm{t} \mathrm{ha}^{-1}\right)$} & & \\
\cline { 2 - 6 } & $\begin{array}{l}\text { Chucmar } \\
\text { Cajamarca }\end{array}$ & $\begin{array}{l}\text { Aurorita La } \\
\text { Libertad }\end{array}$ & $\begin{array}{l}\text { Arcopampa } \\
\text { La Libertad }\end{array}$ & Cañaypata Huancavelica & Combined \\
\hline CIP308478.59 & $33.24 \mathrm{a}^{*}$ & $34.31 \mathrm{abc}$ & $19.54 \mathrm{ab}$ & $11.62 \mathrm{c}$ & $24.68 \mathrm{a}$ \\
CIP308486.355 & $26.52 \mathrm{~b}$ & $35.57 \mathrm{abc}$ & $18.95 \mathrm{ab}$ & $8.02 \mathrm{~cd}$ & $22.26 \mathrm{a}$ \\
CIP308488.198 & $31.83 \mathrm{a}$ & $38.34 \mathrm{a}$ & $18.51 \mathrm{abc}$ & $5.23 \mathrm{c}$ & $23.48 \mathrm{a}$ \\
CIP308488.92 & $35.16 \mathrm{a}$ & $37.26 \mathrm{a}$ & $18.91 \mathrm{bc}$ & $7.69 \mathrm{~cd}$ & $24.75 \mathrm{a}$ \\
CIP308495.227 & $31.52 \mathrm{a}$ & $34.09 \mathrm{abc}$ & $19.51 \mathrm{c}$ & $11.51 \mathrm{~cd}$ & $24.16 \mathrm{a}$ \\
INIA-302 Amarilis & $8.23 \mathrm{c}$ & $21.02 \mathrm{c}$ & $21.66 \mathrm{c}$ & & $19.00 \mathrm{~b}$ \\
INIA-303 Canchan & & $25.46 \mathrm{bc}$ & $20.94 \mathrm{a}$ & $20.57 \mathrm{~b}$ & $20.85 \mathrm{a}$ \\
Yungay & $5.00 \mathrm{c}$ & & & $31.45 \mathrm{a}$ & $18.84 \mathrm{~b}$ \\
\hline
\end{tabular}

*Clones and varieties with the same letter are not statistically different in Waller-Duncan test $(P>0.05)$

\section{Conclusions}

In all localities, using PVS methodology, both men and women identified resistance to LB during flowering and high tuber yield during harvest as the most important selection criteria for new potato varieties.

In Arcopampa and Cañaypta, located more than 3900 masl, frost tolerance and resistance to the Andean weevil were also identified as important selection criteria.

The clones CIP308488.92 and CIP308495.227 were selected as promising clones in Chucmar Cajamarca and La Aurorita La Libertad, locations situated at 2800 and 3700 masl, respectively. In these two locations, these clones had a high resistance to LB and high tuber yield superior to local varieties, INIA-303 Canchan, Yungay and INIA-302 Amarilis, which are susceptible to LB. These clones also have good organoleptic quality and low glycoalkaloid content. The clone CIP308478.59 was selected as promising in Chucmar and Cañaypata, given its wider adaptation. These clones selected as promising should continue trials before they can be recommended for variety registration in mid-elevation and highland environments globally.

Acknowledgements The authors would like to thank Bert de Boeck for statistical support.

Funding This publication has been produced with the financial assistance of the European Union within the framework of the Benefit-sharing Fund project "Biodiverse and Nutritious Potato Improvement across Peru, Nepal and Bhutan" of the FAO's International Treaty on Plant Genetic Resources for Food and Agriculture. This research was undertaken as part of, and funded by, the CGIAR Research Program on Roots, Tubers and Bananas (RTB) and by USAID, supported by CGIAR through the CGIAR Trust Fund Donors (https://www. cgiar.org/funders/).

\section{Declarations}

Disclaimer The views expressed in this document are those of the authors and do not necessarily reflect the views or policies of the European Union or FAO. 
Open Access This article is licensed under a Creative Commons Attribution 4.0 International License, which permits use, sharing, adaptation, distribution and reproduction in any medium or format, as long as you give appropriate credit to the original author(s) and the source, provide a link to the Creative Commons licence, and indicate if changes were made. The images or other third party material in this article are included in the article's Creative Commons licence, unless indicated otherwise in a credit line to the material. If material is not included in the article's Creative Commons licence and your intended use is not permitted by statutory regulation or exceeds the permitted use, you will need to obtain permission directly from the copyright holder. To view a copy of this licence, visit http://creativecommons.org/licenses/by/4.0/.

\section{References}

Abebe GK, Bijman J, Pascucci S, Omta O (2013) Adoption of improved potato varieties in Ethiopia: the role of agricultural knowledge and innovation system and smallholder farmers' quality assessment. Agric Syst 122:22-32. https://doi.org/10.1016/j.agsy.2013.07.008

Arcos J, Gastelo M, Holguin V (2015) INIA 317 - Altiplano, variedad de papa con buena adaptación en la región altiplánica del Perú. Revista Latinoamericana de la Papa 19(2):68-75. https://doi.org/10.37066/ ralap.v19i2.234

Badstue LB, Hellin J, Berthaud J (2012) Re-orienting participatory plant breeding for wider impact. Afr J Agric Res 7(4). https://doi.org/10.5897/AJAR10.1146

Bajgai Y, Dochen T, Wangchuk P, Kadian MS, Felde zum T, Lefebvre M, Lobzang, Arya S, Wangdi T, Gyeltshen T, Wangdi N (2018) Participatory varietal selection of potato and agronomic performance with farmers' feedback on new varieties. Bhutanese Journal of Agriculture. ISSN 2616-3926. 12p

Burgos G, Sosa P, Zum Felde T (2014) Procedures for chemical analysis of potato and sweet potato samples at CIP's Quality and Nutrition Laboratory. Lima, Peru. International Potato Center (CIP), Global Program Genetics and Crop Improvement. $23 \mathrm{p}$

Butler DG, Cullis BR, Gilmour AR, Gogel BG, Thompson R (2017) ASReml-R Reference Manual Version 4. VSN International Ltd, Hemel Hempstead, HP1 1ES, UK

Cuesta X, Andrade H (2001) El Mejoramiento participativo de papa en el Ecuador. INIAP-PNRT-papa. PREDUZA Quito Ecuador

De Haan S, Salas E, Fonseca C, Gastelo M, Amaya N, Bastos C, Hualla V, Bonierbale M (2017) Selección participativa de variedades de papa (SPV) usando el diseño mama y bebe: una guía para capacitadores con perspectiva de género. Lima (Perú), Centro Internacional de la Papa 82pp

Egusquiza R (2000) La Papa. Producción, Transformación y Comercialización. Universidad Agraria La Molina. Convenio ADEX-AID/MSP. Lima, Perú.192 p

Gabriel J, Herbas J, Salazar M, Thiele G (2002) Manual Técnico de Mejoramiento Participativo para Obtener nuevas Variedades de Papa. Promoción e Investigación de Productos Andinos. Proyecto de Mejoramiento Participativo. PROINPA, Bolivia

Gilmour AR, Cullis BR, Verbyla AP (1997) Accounting for natural and extraneous variation in the analysis of field experiments. J Agric Biol Environ Stat 2(3):269-293

Janampa A (2012) "Participatory selection under the mother \& baby design of 20 potato clones Solanum tuberosum spp. andigena (population B1C5), with horizontal resistance to late blight (Phytophthora infestans)." Thesis Agronomist, University for Andean Development. (in Spanish)

John JA (1989) Row-column designs. In: Cyclic Designs. Monographs on Statistics and Applied Probability. Springer, Boston, MA

Klawitter M, Cagley JH, Gugerty MK, Anderson CL, Yorgey G (2009) Gender and Cropping: Wheat in SubSaharan Africa. EPAR Research Brief \#36. Seattle: University of Washington, Evans School of Public Affaird

Labarta R (2015). The effectiveness of potato and sweetpotato improvement programs from the perspectives of varietal output. Crop Improvement, Adoption and Impact of Improved Varieties in Food Crops in SubSaharan Africa, p 164

Landeo JA, Gastelo M, Pinedo H, Flores F (2001) Breeding for horizontal resistance to late blight in potato free of R genes. In Phytophthora infestans 150 proceedings, Dublin Ireland. EAPR, Boole Press pp 268274

Landeo JA, Gastelo MA, Pacheco MA, De Haan S, Diaz L, Puente de E (2008), Two new potato varieties (Solanum tuberosum ssp. andigena) with horizontal resistance to late blight selected by Andean communities through participatory variety selection. Poster presented at: Potato science for the poor; challenges for the new millennium. A working conference to celebrate the International year of the Potato, Cusco, Peru 25-28 March 
Litschmann T, Hausvater E, Doležal P, Petra B (2018) Climate change and its impact on the conditions of late blight occurrence. Sci Agric Bohem 49:173-180. https://doi.org/10.2478/sab-2018-0023

Ministerio de Agricultura y Riego del Peru (2018) http://sissic.minagri.gob.pe/sissic. Accessed July 2020

Morris ML, Bellon MR (2004) Participatory plant breeding research: Opportunities and challenges for the international crop improvement system. Euphytica 136:21-35. https://doi.org/10.1023/B:EUPH. 0000019509.37769.b1

Mudege NN, Mukewa E, Amele A (2015) Workshop report: training on gender integrated potato participatory varietal selection (PVS) in Ethiopia. Addis Ababa, Ethiopia, CIP. 26 p

Pradel W, Hareau G, Quintanilla L, Suárez V (2017) Adopción e Impacto de Variedades Mejoradas de Papa en el Perú: Resultado de una encuesta a nivel nacional (2013). Centro Internacional de la Papa, Lima, Perú. pp 48

Ruprich J, Rehurkova I, Boon PE, Svensson K, Moussavian S, Van der Voet H, Bosgra S, Van Klaveren JD, Busk L (2009) Probabilistic modeling of exposure doses and implications for health risk characterization: glycoalkaloids from potatoes. Food Chem Toxicol 4:2899-2905

Semagn AK, Donald H, Keith P, Walter DJ, Fentahun MT, David W (2015) Identification of farmer priorities in potato production through participatory variety selection. Am J Potato Res 92:648-661. https://doi.org/ 10.1007/s12230-015-9478-0

Semagn AK, De Jong PK, Halseth D, Mengistu F (2017) Participatory variety selection: a tool to understand farmers' potato variety selection criteria. Open Agric 2:453-463. https://doi.org/10.1515/opag-2017-0049

Southeast Asia Regional Initiatives for Community Empowerment (2007) Valuing participatory plant breeding: a review of tools and methods. SEARICE, Manila, Philippines

Storey RMJ, Davies HV (1992) Tuber quality. In: Harris P (ed) The Potato crop, 2nd edn. Chapman \& Hall, London, pp 507-569

Tesfaye TT (2013) Participatory variety selection of potato (Solanum tuberosum L) in southern Ethiopia. Journal of Agri-Food and Applied Sciences. On-line at jaas.blue-ap.org @2013 JAAS J 1(1):1-4

Zuñiga N, Gastelo M, Bastos C, Reyes J, Alania D, Ninalaya E. (2018) Nuevos cultivares de papa con resistencia a la rancha Phytophthora infestans (Mont.) De Bary y adaptación al cambio climático Revista Latinoamericana de la Papa 22 (2): 66 - 82 ISSN: 1853-4961, https://doi.org/10.37066/ralap.v22i2.305

Publisher's Note Springer Nature remains neutral with regard to jurisdictional claims in published maps and institutional affiliations.

\section{Affiliations}

\section{Manuel Gastelo ${ }^{1}$. Gabriela Burgos ${ }^{1}$. Carolina Bastos ${ }^{2}$ - Juan Miguel Perez ${ }^{3}$. Ronal Otiniano ${ }^{3} \cdot$ Hector Cabrera ${ }^{4} \cdot$ Raul Ccanto $^{5} \cdot$ Maria Mayer de Scurrah ${ }^{5}$. Thomas zum Felde ${ }^{1}$}

1 International Potato Center, Lima, Peru

2 International Potato Center, Huancayo, Peru

3 NGO Asociacion Pataz, La Libertad, Peru

4 National Institute of Agrarian Innovation, Cajamarca, Peru

5 NGO Yanapai, Huancavelica, Peru 